\title{
REFLECTION
}

\section{Racism in Medicine: Shifting the Power}

\section{J. Nwando Olayiwola, MD, MPH, FAAFP}

Center for Excellence in Primary Care, San Francisco General Hospital, San Francisco, California

Department of Family and Community Medicine, University of California San Francisco, San Francisco, California
Conflicts of interest: author reports none.

\section{CORRESPONDING AUTHOR}

J. Nwando Olayiwola, MD, MPH, FAAFP San Francisco General Hospital 1001 Potrero Avenue Ward 83, Room 314B San Francisco, CA 94110

OlayiwolaJ@fcm.ucsf.edu

\begin{abstract}
Medicine has historically been a field where the provider of the service (physician, nurse) has a significant amount of power as compared with the recipient of the service (the patient). For the most part, this power is relatively consistent, and the power dynamic is rarely disrupted. In this essay, I share a personal experience in which a racist rant by a patient seemingly reverses the power dynamic. As the physician, I faced the realization that I may not have as much power as I believed, but fortunately I had some tools that allowed for my resilience. It is my hope that this paper will strengthen other family physicians and professional minorities that are victims of racism, discrimination, and prejudice for their race, sex, ability, sexual orientation, religion, and other axes of discrimination.
\end{abstract}

Ann Fam Med 2016;14:267-269. doi: 10.1370/afm.1932.

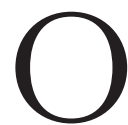
$\mathrm{n}$ most days, in my professional life, I feel powerful. I have a unique privilege that a small percentage of people in the world have. I am a doctor. A physician. Or as my parents love to say, a medical doctor. Because of the support of my parents and family, I have been well educated and trained. I went to a top medical school. I trained at a top family medicine residency program. I did a fellowship in minority health policy and Masters in Public Health at Harvard School of Public Health. And now, over 10 years after completing the fellowship, I am a physician faculty member at the University of California, San Francisco, where I practice at San Francisco General Hospital.

While the nation around me is experiencing anguish from racially charged incidents, there is often an insulation that comes with practicing medicine. In the morning, I drop my kids off at school and pray that they have a good day, and that no one hurts them emotionally or physically. I pray that they will continue to be embraced, encouraged, and fulfilled, and that my insulation extends to them, regardless of the color of their skin. I think about this every single day. Then I commute to work having an internal sense of awareness that I am a black woman. At the train station, I get stares from some people and am ignored by others. No one knows who I am, and for the most part, no one on my commute cares. This selfawareness is something that has built over time.

But then, something almost magical happens. I get to work and as I put on my white coat, my doctor's white coat, I instantly get superpowers! All of a sudden, people who ignored me or stared at me realize that I'm someone. And not just anyone. Someone with power, with authority, and with a vast amount of knowledge.

Yesterday I was reminded how quickly a sense of power can shift. In the morning, I walked into the clinic building without my superhero coat on, and I saw one of the sheriffs, whom I greeted, "Good morning!" She ignored me, though I was directly in front of her. I went upstairs and transformed...got my white coat and stethoscope and headed back down the elevator to go to my clinic. "Good morning," I said again. She looked at my coat, my badge and the large identifying "DOCTOR" badge we are required to wear and said, "Oh good morning, doctor. Sorry about 
before!" Voila! Just like that, I went from being unworthy of a morning greeting to worthy of an apology. The power was now well shifted in my favor. I went to my clinic feeling very powerful ... until I saw my first patient of the day.

I had seen this patient once before and I knew he had some mental health issues. As he and the case worker entered the room and I introduced myself, he refused to shake my hand. "No way, no way, no way," he said. He turned to his case worker: "You didn't tell me I was going to see a black doctor. And not just a black doctor, but a black woman!" She looked at me in disbelief and mouthed, "Sorry." "There is no way I am letting a black woman take care of me. Black women are the problem with this whole country and the whole world. No way, no way, no way..." He continued to rant. "What happened to the real doctors, the white doctors? Black people are taking over everything! Everywhere I look, there are niggers!" While his mental illness was certainly in play, deep and visceral values and beliefs are not solely a manifestation of mental illness, they just become more lucid and less-filtered for those with mental illness.

Immediately the power was shifted. I was no longer a superhero in a white coat. He saw through the white coat and all I was to him was a black woman, now in an awkward position. To him, I was the image of society's often-negative portrayal of "the black woman," and every stereotype that conjured up for him. In a split second I asked myself so many questions: "Do I have to see this patient?" "Is there a hospital policy about this?" "Is there a white doctor he can see?" "Can I kick him out of my exam room?" "Can I go off on him?" "Will I get in trouble if I do?"

As the patient continued to rant, I found myself doing what the powerless $\mathrm{do}_{i}$ I tried to prove myself. I was now explaining to the patient and the case worker that I was qualified to take care of him, that I did go to medical school and have been in practice for many years. It's a common reaction, which I have seen with my patients - the woman who is a victim of domestic violence trying to explain her worth to her oppressor; the victim of human trafficking explaining her value to her pimp; the Muslim female who has to prove that she is not a terrorist before she can register for care ${ }_{i}$ the Chinese-American college student trying to prove to his classmates that he is an American and deserves to be here.

Black women (and other professional minority women) have to justify professional qualifications that should speak for themselves. We have to be "twice as"...good, smart, talented, aggressive, outspoken, witty, etc than everyone else in our professional or work environments; proving that we are not "impos- ters," biting our tongues and tempering our words because we don't want to appear "angry;" being passed up or looked over, underpaid, undervalued, and underappreciated. In this moment, I was no different than any of my patients and in fact, I wished some of them were there to see how my power had changed.

We negotiated through this visit-I told the patient that we could focus on his blood pressure for today and he could see another doctor next time. When I asked about his symptoms, including chest pain, he said, "I don't have to tell you anything." and "I didn't have chest pain until I saw you were my doctor." We moved to the section where I would do his exam. "Okay but I'm not letting your black hands touch me!" We bartered on what he would agree to- "I'll get the labs done only if that white lady, who I can trust, will do it." "You can listen to my heart but that's it." "Don't touch me anywhere else." And somehow, we finished this visit. I ushered him off to the nurse for his laboratories and closed my door.

Too sad to cry, too hurt to feel, too paralyzed to move, and too embarrassed to come out of the room, I sat and pondered over what happened. Racism had just completely and tectonically shifted the power away from me. Racism stripped me of my white coat, my stethoscope, my doctor's badge, my degrees and credentials, my titles, my skills, and my determination to serve. Racism showed up in that moment as the perfect antidote to my superpower. Like kryptonite to Superman. I reflected on this the rest of the morning. How would I tell this story? What would the take-home lesson for my students and residents be? Was there more I could have done? Should have done?

My last patient of the morning, an older black woman who is always so supportive of me, came very late. When they asked if I would still see her, I said yes. Every time she sees me, she tells me how proud she is of me. As we talked about her, I found myself describing this earlier encounter. This was a purposeful shift of power. I needed her. I became completely vulnerable as I told her what happened. I told her, "I acted like a total punk. Sat there and negotiated with this man on what I could do to care for him. I was completely powerless."

And she said to me: "My dear, you interpreted it ALL wrong. Anyone who lives their life in fear of YOUR power and accomplishments, and who cannot get past that, even for their own health, is the weak one. You hold your head high because you are still the same great doctor you were before you saw him. He can never take that away from you. He has to go home... and wrestle with his own demons. Darling, in that encounter, you had all the power in the world!"

She was right. I really did have a lot to be proud of, and I thought about how I had developed resilience 
over time. I had a similar experience with a white swastika-bearing patient when I was a family medicine resident, who said all black, Hispanic, Asian, and Jewish doctors should be burned alive; another encounter as a physician in Connecticut with a patient who said she'd rather die than be touched by a filthy black doctor; and many more macro-aggressions as well as micro-aggressions. Such is the life and experience of professional minorities.

So how and why am I still doing this work? As a family physician, I fundamentally believe that we are responsible for the whole health of our patients, and deep-rooted racism is part of poor health. But, I can honestly say that I have developed thick skin over the years, and a number of strategies to handle the aggressions I have experienced from patients, colleagues, and institutions, though none is perfect. One important strategy is to remind myself that I am NOT overreacting. No one can quantify or categorize the level of offense I feel, so even if the person beside me minimizes what I experienced, I stand firm about what the aggression meant to me.

Additionally, I know that in most situations, I can control how long I have to stay and listen. If I really feel like I cannot endure any more, I have the power and privilege to leave the situation, whether it's an individualized aggression or a systematic one. It may not be easy, but sometimes leaving a situation is the best way to de-escalate it. If there are others witness- ing the situation, it is my hope that they would speak up where I cannot, and help build a larger dialog around the problem.

Also important is that I accept that I cannot fix the victimizer. Not only am I unlikely to yield much change in that moment, trying to force the abandonment of such harsh thoughts can be emotionally exhausting and draining. Over time, and through the relationships that we build with people, there is an opportunity to understand our biases, to hear about other perspectives, and come to common ground.

Finally, and perhaps most important, I remember that I deserve to be where I am. No one studied for me. No one did my exhausting on-call responsibilities for me. No one went through the challenges and perils of rigorous academic and training programs for me. This is probably the hardest lesson for me to exert but the most obvious one - I deserve to be here. I am black, of African descent, a woman, someone with a long last name, and so much more, and my seat at the table has been earned not given. And no racist rant can ever take that away.

To read or post commentaries in response to this article, see it online at http://www.annfammed.org/content/14/3/267.

Key words: racism; racial discrimination; minority groups; prejudice; medicine; health care delivery

Submitted September 23, 2015; submitted, revised, January 7, 2016; accepted January 26, 2016. 